\title{
Adnan Jahić, MUSLIMANSKO ŽENSKO PITANJE U BOSNI I HERCEGOVINI (1908-1950), Bošnjačka nacionalna zajednica za Grad Zagreb i Zagrebačku županiju, Zagreb 2017, 552 str.
}

Naučna javnost Bosne i Hercegovine, posebno ona koja se bavi ili se zanima za rezultate historije i srodnih nauka teško da je dovoljno svjesna velikih zasluga i značaja koji je Bošnjačka nacionalna zajednica za Grad Zagreb i Zagrebačku županiju imala posljednju deceniju na planu razvoja historiografije Bosne i Hercegovine i Bošnjaka. Pod vodstvom i uredništvom (nažalost, prerano preminulog) Dževada Jogunčića, a u okviru izdanja „Biblioteke Bosana“, Bošnjačka

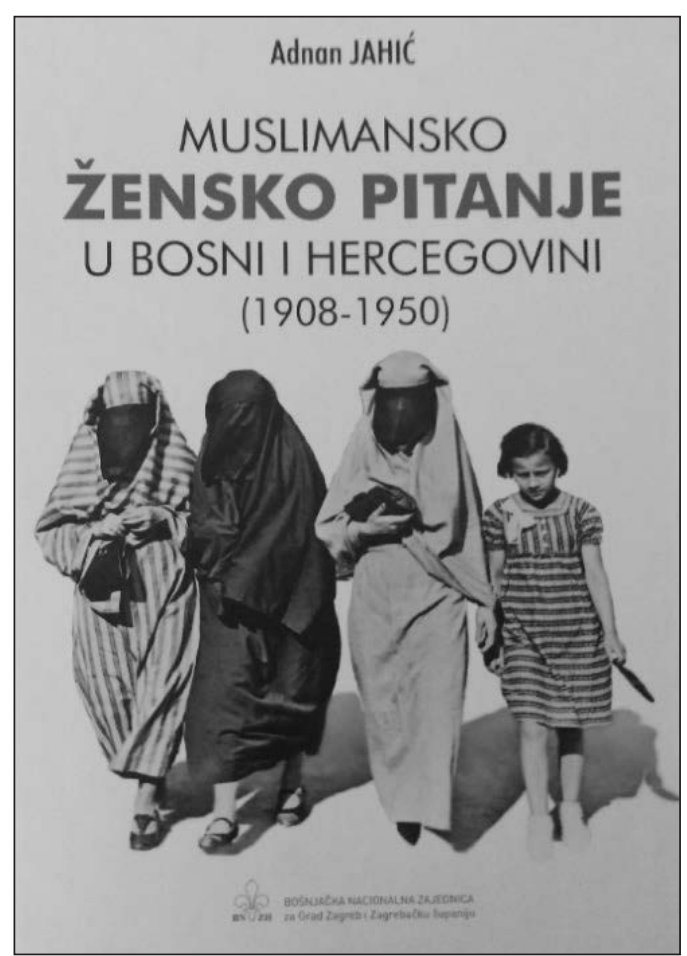
nacionalna zajednica za Grad Zagreb i Zagrebačku županiju izdala je niz značajnih naučnih djela koja su se bavila historijom Islamske zajednice u Bosni i Hercegovini, Jugoslovenske muslimanske organizacije i drugim ključnim momentima i organizacijama iz naše historije. Listi objavljenih kapitalnih djela ovog renomiranog izdavača 2017. godine dodato je i djelo prof. dr. Adnana Jahića, redovnog profesora katedre za historiju Filozofskog fakulteta Univerziteta $\mathrm{u}$ Tuzli, naslovljeno Muslimansko žensko pitanje u Bosni $i$ Hercegovini (1908-1950).

Suizdavač ovog djela je Naučnoistraživački institut „Ibn Sina“ Sarajevo, a obaveze urednika preuzeo je prof. dr. Sead Berberović. Recenzije su uradili naučnoj javnosti Bosne i Hercegovine poznati historičari, prof. dr. Husnija Kamberović, prof. dr. Adnan Velagić i dr. sc. Fabio Giomi. Knjiga je vizuelno obogaćena i koricom dizajniranom od strane prof. dr. Mehmeda Akšamije. Djelo nosi podnaslov Žena u intelektualnom i društvenom životu Bošnjaka od aneksije do Zakona o zabrani nošenja zara i feredže (1908-1950), te isti 
ponajbolje i informira o fokusu i pristupu temi. I na prvi pogled je jasno da je ova knjiga, posvećena muslimanskom ženskom pitanju, kulminacija višestrukih i detaljnih istraživanja niza primarnih izvora i literature. Žensko pitanje bilo je zanemareno u bosanskohercegovačkoj historiografiji, a kako i sam autor navodi, slika o prošlosti jednog naroda ne može biti kompletirana bez uvida u njegov odnos prema ženi. Taj odnos je, ovo djelo nam otkriva, kompleksan i obojen vjerskim, tradicionalnim, ideološkim i drugim biljezima. Stoga je posebno vrijedno nastojanje autora da ponudi objektivan prikaz stanja i prilika, bez ideoloških ocjena ili kvalifikacija kakva je, kako sam ističe, znala biti relevantna literatura o ženskom pitanju vođena vladajućim političko-ideološkim prioritetima u bivšoj, socijalističkoj državi.

U samom uvodu čitalac se može upoznati sa prethodnim rezultatima istraživanja, te radovima pisanim na temu ženskog pitanja u Bosni i Hercegovini, kako u socijalističkom, tako i postsocijalističkom periodu. Jahić tako naglašava da je muslimansko žensko pitanje jedno od ishodišta koje su donijele promjene $u$ društveno-ekonomskim odnosima u Bosni i Hercegovini pod austrougarskom upravom, kao i u političkom, kulturnom i vjerskom životu Bošnjaka na razmeđu 19. i 20. stoljeća, potičući svjesniji dio bošnjačke intelektualne elite i javnosti da problematizira stanje i položaj, te mjesto i ulogu žene u očekivanoj narodnoj obnovi $i$ prilagodbi novonastalim međunarodnim, kulturno-civilizacijskim $i$ društvenim datostima koje je donijelo novo doba. Jahić jasno ističe da u patrijarhalnom društvu, kakvo je naše bilo (i dalje jeste), sliku o ženi grade muškarci, te da u skladu s tim arhivska građa, štampa i drugi izvori donose mahom mušku sliku o muslimanki, ali da je u rijetkim prilikama kada su pružene, u historiografsku sliku „ugrađivao“ i glasove žena, djevojaka, intelektualaca liberalnih shvatanja, ostavština šerijatskih sudova i dr. izvora koji bi dali potpuniju sliku o ženi u posmatranom periodu.

Prvo poglavlje knjige nosi naziv Dosta neozbiljna brošura. Odmah saznajemo da se radi o brošuri koju je štampao Dževad-beg Sulejmanpašić, i kojom je predstavio jedan prilog rješenju „našeg muslimanskog ženskog pitanja“. Sulejmanpašić je naglasio da su muslimani zanemarili ženski naraštaj čime su ugrozili svoj opstanak u Bosni i Hercegovini, a muslimanku osudili na bijedu i zaostalost. Predložio je temeljite promjene koje bi bile prilagođene „novom“, austrougarskom vremenu. Konzervativna bošnjačka elita odgovorila je javnim spaljivanjem brošure u haremu Gazi Husrev-begove džamije u Sarajevu. U ovom fascinantnom poglavlju autor knjige daje jasan prikaz stanja muslimanke u prvih četrdeset godina od austrougarske okupacije, te stavove uleme i inteligencije prema ženskom pitanju, odnos konzervativnih i reformističkih krugova prema istom, odnos austrougarske uprave, koji je redovno oportunistički i dr. Sam naslov poglavlja dolazi od ocjene koji je brošuri dao Hasan M. Rebac, 1925. godine.

Drugo poglavlje nosi naziv Koja škola treba muslimanki? i u istom čitalac ima priliku upoznati se sa posljedicama austrougarske aneksije za Bošnjake, odnosno sa reakcijom bošnjačke političke i intelektualne elite na aneksiju, te sa 
odnosom prema školstvu i obrazovanju (koji je opet bio obilježen svojevrsnom „traumom“ aneksije) i mjestom žene u istom. Kako autor ističe, kada je riječ o odnosu bosanskomuslimanskog vjerskog vodstva prema školovanju muslimanke pod austrougarskom upravom, njegova stajališta su demonstrirala prioritete u kojim su čednost $i$ moralni lik žene bili daleko iznad prosvjetnih i obrazovnih imperativa, pri čemu su očuvanje morala i pohađanje škola pod ingerencijom države nerijetko posmatrani u okvirima kolizije i sukoba, a ne kao dva komplementarna stremljenja $u$ funkciji jačanja ličnosti $i$ digniteta žene u savremenom dobu. Poglavlje je, kao uostalom i ostatak djela, izuzetno bogato citatima, izvještajima iz štampe i periodike, brošura i drugih izvora.

Treće poglavlje nosi naziv (Ne)moral na margini velikog rata, te se bavi stanjem u kojem se muslimanska žena našla tokom Prvog svjetskog rata. Autor daje prikaz situacija i stanja u kome su se žene našle kao posebno osjetljiv dio ratom obilježenog društva, te percepciji i reakciji istog prema izvanbračnim odnosima (konkubinat sa vojnicima), poligamiji, brakovima sa maloljetnicama, prostituciji. Suočena sa ovim pitanjima i problemima, ulema je 1918. godine formirala Odbore za suzbijanje nemorala, i to kao krajnji izraz mentaliteta i nastojanja patrijarhalne zajednice da se žena zaštiti od izazova modernog društva, ne dirajući u idejnu osnovu njenog socijalnog položaja.

Četvrto poglavlje, pod imenom Ujedinjenje: surova stvarnost $i$ nove inicijative govori o poslijeratnom periodu. Nakon rata, navodi Jahić, aktivnost uleme dobila je nove forme kroz više inicijativa kojim se nastojalo osposobiti muslimanku da se odupre siromaštvu i moralnoj degradaciji, što bi vodilo ozdravljenju društva i sprečavanju urušavanja ukorijenjenih etičkih i društvenih normi. Treba li muslimansko žensko pitanje biti svedeno na potrebu ženine opskrbe, kako bi se sačuvalo njeno moralno biće, bez zadovoljavanja njenih duševnih $i$ društvenih potreba, pojavilo se kao problem i slaba tačka napora bošnjačkog društva u iznalaženju odgovora od kojih je, naročito nakon 1918. godine, očito ovisila putanja razvoja bošnjačkog društva.

Peto poglavlje, naslovljeno Emancipovanje govori o periodu Kraljevine Srba, Hrvata i Slovenaca, sa fokusom na djelovanje „Gajreta“, a „emancipovanje“ koje se javilo među dijelom bošnjačke elite u prvi plan stavljalo je savremeno obrazovanje i buđenje nacionalne svijesti (mahom srpske) kod muslimanke. Drugi dio elite pak zagovara konzervativniji pristup, sa naglaskom na moralu i časti žene. Poglavlje se završava sa stavovima Ahmeta Ljubunčića koji je obrazložio, treći „srednji“ put za muslimansku ženu - put „evolutivnog podizanja“, a koji naglasak stavlja na sistematski prosvjetni rad u širokim narodnim slojevima. $\mathrm{Na}$ bazi Ljubunčićevih stavova započeti će izlaženje „Đulistana“, prvog muslimanskog ženskog časopisa u Bosni i Hercegovini.

Đulistan je ujedno i naziv šestog poglavlja knjige, koje se, očekivano, bavi radom ovog časopisa za „kulturno i socijalno pridizanje muslimanske žene“, a koji je nastupao sa „programom“ izrađenim sa ciljem da pomiri konzervativne i 
progresivne krugove. Po navedenom programu, ženi je potrebna emancipacija, ali nakon „temeljite“ pripreme, koju list nikada nije preciznije odredio ili definirao.

Sedmo poglavlje djela, naslovljeno Baška Turci, baška Ljubušaci, iscrpno čitataoca informira o debati među bošnjačkim elitama po pitanju „otkrivanja ili pokrivanja“ žene muslimanke, a iz onovremenih (1928. godina) časopisa, brošura i dr. izvornog materijala autor zaključuje, a čitalac će se složiti, da su vjerski učenjaci, čaršijski elementi, svjetovna inteligencija, kulturni radnici $i$ dr. narodni slojevi demonstrirali krajnje oprečna gledanja na pitanje položaja muslimanske žene u savremenom društvu.

Ove oprečnosti koje su se manifestirale među bošnjačkom elitom autor nastavlja analizirati i u osmom dijelu knjige, nazvanom Tradicija $i$,savremeni život“. Moda, korzo i prostitucija. Jahić, između ostalog, navodi da u prvoj polovini tridesetih, očito, bošnjačko društvo je još uvijek patilo od karakterističnih slabosti - pomanjkanja socijalne kohezije i nedovoljne organiziranosti praćene pomućenim prioritetima i konzervativnim pogledima na realnosti novog doba. U shvatanjima konzervativnih krugova postojala je tanka linija između mode, korza i koketiranja, te prostitucije i razvrata. Iza širenja prostitucije, koje je bilo evidentno, neki savremenici (1936. godine) držali su da stoje faktori kao što su kino, romani, ples, muzika, društveni razgovori, pornografske slike, hrana, piće, korzo, teferiči i zabave, praćeni manjkom ,pravilnog odgoja“ ženske čeljadi. Analizirajući brošure i tekstove iz ovog perioda, autor knjige postavlja pitanje da li je iza učestale kritike savremenog života doista stajala spremnost za suočavanje sa izvorima nemorala $i$ prostitucije ili ponajprije potreba da se uklone vidljive strane moralne krize koja je remetila duševni mir gradskih elemenata i odgovorne elite? Poglavlje iznosi pregršt interesantnih, ponekad i potresnih sudbina i priča koje su ostale zabilježene, a govore o muslimankama koje su se, nespremne i ponekad naivne, suočavale sa izazovima i iskušenjima ,novog vremena“ u patrijarhalnoj sredini. Posebno su zanimljivi detalji o izboru za „Miss“ i reakcijama na isto, te djelatnost „Gajreta“ kao glavne društvene snage u pravcu prosvjetnog i ekonomskog podizanja muslimanske žene u monarhističkoj Jugoslaviji i dr.

Deveto poglavlje, Od bule do doktora daje nam sliku daljih promjena i sve većeg broja školovanih Bošnjakinja u obrazovnim ustanovama jugoslavenske države, iako se ipak još uvijek radi o simboličnom broju naspram ukupne populacije bošnjačkog ženskog stanovništva. Poglavlje se bavi i osnivanjem ženskih medresa, pojedinim visokoškolovanim Bošnjakinjama u Kraljevini Jugoslaviji i dr.

Poglavlje Između četiri zida: udaja i brak, deseto po redu, posebno je upečatljivo i daje objektivnu ocjenu uloge braka u periodu tridesetih godina dvadesetog stoljeća. Kako Jahić ističe, patrijarhalno bošnjačko društvo nije smatralo umjesnim otvarati raspravu o ljubavi, emocijama i karakteru muško ženskih odnosa; (...) insistiralo je na formalnim aspektima skladne i funkcionalne bračne zajednice. (...) Za jugoslavensku ženu, bez razlike vjere, osnovni prioritet bilo je - udati se i zasnovati porodicu, manje je bila važna osoba za koju se udaje, 
njena narav i sklonosti, posebno ako je bila situirana i kadra izdržavati je. $\mathrm{Ni}$ primjena šerijatskog prava po kojem je muslimanka mogla biti u boljem položaju u odnosu na pripadnice drugih vjera, nije prakticirana u korist žene. Na osnovu sudske i druge dokumentacije, poglavlje iznosi slučajeve razvoda brakova, te napuštanja žena od strane njihovih muževa, ali i obratno, slučajeva kada je žena iz različitih razloga napuštala muža. Autor posebnu pažnju posvećuje i mješovitim brakovima, te njihovoj percepciji u bošnjačkom društvu.

Jedanaesto poglavlje, naslovljeno $U$ vremenu nasilja, nereda $i$ isključivosti (1941-1945) bavi se periodom Drugog svjetskog rata, sa osvrtima na stavove ustaškog pokreta prema ženama i njihovoj ulozi, novoj imperativnoj ulozi žene u prihvatanju izbjegličke nejači i siročadi i obnovi u sredinama koje su pretrpjele razaranja. Autor daje i mnoštvo podataka o četničkim zločinima nad bošnjačkom ženom, koja je bila izložena bacanjima u jame, grupnim spaljivanjima i klanjima, silovanjima i poniženjima druge vrste. Mnoge žene i djevojke pokazale su nesvakidašnju hrabrost $i$ upornost u nastojanjima da prežive, sačuvaju svoju čast, zaštite svoju djecu (...), zaključuje Jahić. Niz informacija iznesenih u poglavlju odnosi se i na žene koje su uzele učešća u NOB-u.

Revolucija i emancipacija dvanaesto je i posljednje poglavlje knjige, te se bavi ulogom bosanskohercegovačke žene u socijalističkoj, poslijeratnoj Jugoslaviji. Predmet analize autora pitanja su poput djelovanja Antifašističkog fronta žena (AFŽ), ideološki stavovi KPJ prema ženskom pitanju, analfabetski tečajevi za žene, djelovanje „Mladih muslimana“, inicijative za skidanje zara i feredže i drugo. Čitaocu postaje jasno da inicijative za skidanje zara i feredže nisu urodile plodom, te se vladajuća partija na kraju odlučila za donošenje zakonske zabrane, kojom bi konačno riješile ovo pitanje.

U zaključku autor daje kratku ocjenu problematike na osnovu svega izloženog, te između ostalog rezimira da je komunistički režim suočio bošnjačku ženu sa izazovima otuđenja od vlastitih vjerskih i tradicijskih korijena, dovodeći je u neposredni doticaj sa sistemom vrijednosti koji je relativizirao naslijeđe, kulturu i identitet Bošnjaka. No, on joj je, također, suočivši je s pravom i odgovornošću izbora, otvorio prostor obrazovne, profesionalne i društvene emancipacije, bez čega ne bi bila moguća njena savremena afirmacija, kako u bivšoj socijalističkoj državi, tako i u postsocijalističkom društvu samostalne i demokratske Bosne i Hercegovine.

Nikako ne možemo okončati prikaz ove knjige a da se ne osvrnemo na bogat i historičarima posebno važan dio iste koji daje podatke o izvorima i literaturi koju je autor koristio pri izradi knjige. O serioznosti knjige ništa ne govori bolje od velikog broja arhivskih fondova i zbirki iz Arhiva Bosne i Hercegovine, Arhiva Hercegovačko-neretvanskog kantona, Arhiva Jugoslavije, Arhiva Tuzlanskog kantona, Historijskog arhiva Sarajevo, Gazi Husrev-begove biblioteke, Hrvatskog državnog arhiva, Muzeja Tešanj i drugih ustanova. Navedeno je ukupno 50 primarnih izvora, čuvanih u navedenim ustanovama, a korištenih pri izradi ove studije. Dodatno, korišteno je 30 objavljenih izvora i službenih publikacija, te 89 
različitih novina, časopisa i ostale periodike. Bogata lista korištene literature broji 69 članaka i 165 knjiga i brošura. Uz navedeno, knjiga uključuje i prevod zaključka na engleski jezik, te kazalo imena.

Na kraju, možemo istaći da je knjiga prof. Jahića temeljito istražena studija o muslimanskom ženskom pitanju od aneksije 1908. do donošenja Zakona o zabrani nošenja zara i feredže 1950. godine, koja rasvjetljava slabo istraženu žensku historiju u bosanskohercegovačkoj historiografiji. Jasno je da žensko pitanje nisu otvorile žene muslimanke, već ga je postavila bošnjačka elita, ali ova knjiga bez ikakve sumnje obogaćuje naša znanja o ovom aspektu društvene historije i daje nam pregršt podataka i analiza o ulozi i perspektivi bošnjačke žene u društvu, te će, nadamo se, biti podstrek i povod nizu budućih istraživanja srodnih tema iz sfere društvene i intelektualne historije. 